was persuaded to stay on for another term. Mr. Mohamed Afifi (Morocco) was appointed assistant to the honorary secretary. The honorary treasurer is Dr. Vladimir Vaclavek (Czechoslovakia). The honorary life members remain M. Jean Painlevé (France) and Mr. Jan Korngold (Poland). The editorin-chief of Scientific Film, the journal of the Association, is Mr. Maurice Goldsmith (Great Britain).

The liaison officer of the Association with the International Science Film Library is Mr. Luc
Haesaerts (Belgium); the chairman of the Television Study Commission is Mr. John Maddison, and of the Unesco-International Scientific Film Association Science Films Commission, Mr. Bernard Chibnall (Great Britain). The chairmen of the Standing Committees are: Research, Dr. R. Robineaux (France); Popular Science, Mr. V. Tosi (Italy); and Education, Prof. J. Jacoby (Poland). Next year's Congress is likely to be held in Rabat, Morocco. Maurice Goldsmith

\title{
A BRITISH SOURCE OF NATURAL GAS
}

$\mathrm{T}$ HAT in Britain there should be in daily use a supply of natural gas may well surprise many well-informed people. Indeed, it was in 1938 that two discoveries of natural gas in Britain were made, one at Cousland, south-east of Edinburgh, and the other west of Whitby at Eskdale. At that time no commercial outlet existed for these potential supplies and the wells were sealed off for eventual future use. The Cousland discovery has been harnessed by the Scottish Gas Board for the use of Musselburgh, where after being suitably treated it forms part of the gas supply.

Now there comes the news of interest more particularly to the inhabitants of the Whitby district of tho actual utilization of the gas from the Eskdale area. The wells are situated in moorland of much natural beauty; but there is no fear that the amenities of that fair land will be impaired by tho small surface equipment that marks the source of a sufficient supply of gas to serve a new but sole production unit in the Whitby Gas Works.

Two wells, of some eleven that have been drilled, have proved to be gas producers. These wells have a closed pressure approximating to $2,000 \mathrm{lb}$. per sq. in., and draw their gas from limestone layers, rospectively 4,196 and $4,807 \mathrm{ft}$. below ground-level. It was only in April this year that these wells were re-opened and now the laying of a 3 -in. pipe-line has been completed. Further, in order to produce from the natural gas, which contains 93-94 per cent of methane and has a calorific value of 1,000 B.T.U. per cu. ft., a final gas for public distribution of 500 B.T.Y. per cu. ft., a conversion plant has also been installed.

The conversion process of the gas is known as a reforming process. It consists essentially of the reaction of the natural gas with steam to produce hydrogen and carbon monoxide. It is carried out in special heat-resisting steel tubes which are heated to about $1,100^{\circ} \mathrm{C}$. and contain a nickel catalyst. It is then enriched with some cold natural gas, and flue gas from the tube-furnace, fired by natural gas. This is necessary to adjust it to the correct calorific value and density for public distribution.

It is also interesting to note that the gas is of such a freedom from sulphur impurity that in order to ensure that gas supplied to the town should have a distinct odour, equipment for the purpose has been installed, employing tetrahydrothiophen as odorant.

The two wells available have a combined flow-rate up to $4 \cdot 5 \mathrm{~m}$. cu. ft. per day. Three reformer units have been provided, each having a daily capacity of $625,000 \mathrm{cu}$. ft.

The plant has been put to work in recent weeks, and the venture is so new that the performance tests have yet to be carried out. R. J. SARJANT

\section{THE LIBRARY IN SCIENCE AND TECHNOLOGY}

$\mathrm{O}^{\mathrm{r}}$ the papers of scientific interest presented at the annual conference of the Library Association at Scarborough, September 12-16, that of Dr. D. J. Urquhart describing the planning of the National Lending Library for Science and Technology and the ideas and motives behind it is undoubtedly the most irnportant, but some of the other papers should not be overlooked by the scientist and technologist. In his presidential address on September 13, Mr. B. S. Page, librarian of the Brotherton Library, University of Leeds, discussed librarianship as he saw it practised in English universities of the twentieth century, and more particularly the research side of such work. Research, he suggested, in fact determined the extent, and very largely the character, of the collections and greatly influenced every aspect of the work of a university librarian, and Mr. Page emphasized, first, that the librarian and his readers were members of the same university community, with all it implied, and secondly, that the reader regarded the library less as an amenity than as a necessity; his use of it was regular and professional ; normally his work could not proceed without it, and how it operated made an immense difference to the reader's peace of mind and perhaps his hopes for the future. From this Mr. Page argued that because selection had to make the most of very limited resources, buying must be largely related to specific interests which have to be known and understood by the library staff, while at the same time important works had to be acquired for future needs and a closo watch kept over special collections and special emphases in general colloctions. The librarian must be thoroughly equipped to make the most of the potential cooperation of the experts in the teaching departments surrounding him and, pointing out that a university 